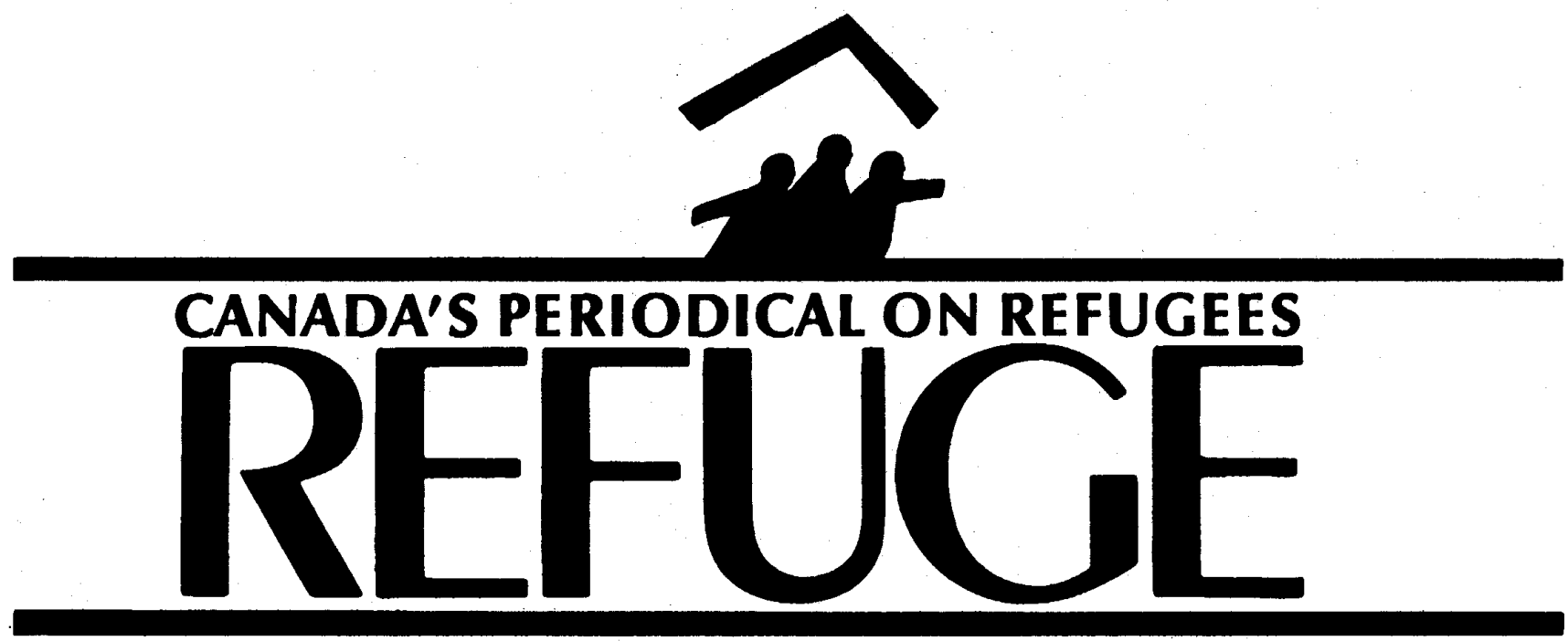

Vol. $14 \cdot$ No. 3

Special Issue on the Former Yugoslavia

June-July 1994

\title{
Aiding and Abetting: Refugee Politics in the Territories of the Former Yugoslavia
}

\section{Edith S. Klein}

Probably the most vivid images in Western minds of the wars in Croatia and in Bosnia-Herzegovina are those of columns of people marching away from their burned-out villages, or of children leaving their parents and boarding buses to escape from their war-ravaged cities. These images are more than merely symbolic. Indeed, the massive movement of citizens of the former Yugoslavia away from their homes-whether a farm in a village caught in the crossfire, or a city apartment located on the wrong side of a bridge-is the central feature driving the war brought on by the collapse of the former Yugoslavia.

One of the common features of the many political crises of the post-Cold War era has been intense conflict between members of ethnic groups that had formerly lived together in the same state. With the disintegration of the federal states of Czechoslovakia, the Soviet Union, and Yugoslavia, the idea of re-associating populations with territories seems to have remarkable appeal. Indeed, each successive war in

\section{CONTENTS:} Michael Barutciski
Europe has shifted boundaries slightly in favour of conterminous territorial and demographic units. Thus, while there is nothing essentially new in the idea itself, it has managed in an unusually short period of time to launch

newly formed political parties into power and armies into war. Observers of these crises, as well as participants, debate the reasons for the dramatic resurgence of ethnic antagonisms, but on one point there would surely be

Aiding and Abetting: Refugee Politics in the Territories of the Former Yugoslavia Edith S. Klein.

Pandora's Wars: The Multi-Dimensional Nature of the Yugoslav Conflicts Slobodan Drakulic

From State Socialism to State Nationalism:

The Case of Serbia in Gender Perspective Zarana Papic

National Identity As Political Ideology Zdenka Milivojevic 15

The Yugoslavian Puzzle: Which Nationalism, Whose War, and Other Unsettling Questions Nergis Canefe Günlük

Crisis in Bosnia-Herzegovina and the Myth of Preventive Protection Michael Barutciski

Undermining the Refugee Convention: Germany's

Civil War Clause and Temporary Asylum: Albrecht Schnabel ..... 30

EU States and the Refugee Crisis in the Former Yugoslavia 


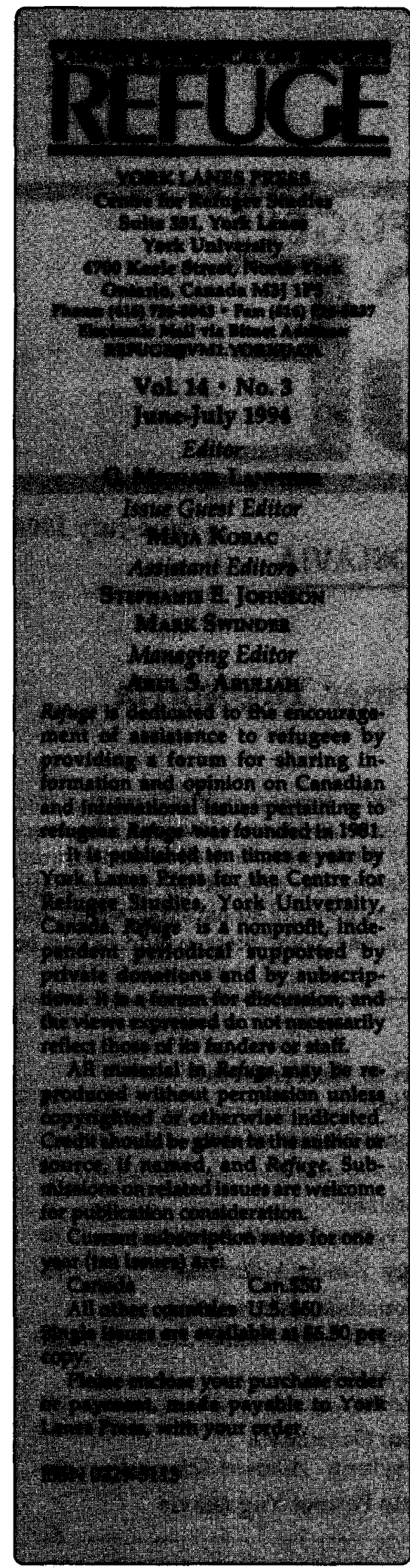

agreement: the redrawing of borders to accommodate ethnocultural communities, or the accommodation of ethnocultural communities to existing borders, will in either case require massive population movement. At present, these alternative scenarios are being fought over in the regions of former Yugoslavia.

While all wars produce refugees, ${ }^{1}$ the displacement of civilians in the territories of the former Yugoslavia has reached massive proportions. By the end of 1993, it was estimated that approximately one in five persons had been displaced by the war ( 4.2 million people out of a prewar population of 22 million), with the largest displacement occurring in the first six months of 1993, i.e., in the wake of intensification of the Bosnian conflict. ${ }^{2}$ Yugoslav refugees, civilians forced out of their homes at gunpoint or through deprivation of life-sustaining needs, or escaping before the onset of direct combat, fled in many directions: some to Serbia, some to Croatia, others to third countries (abroad), while many were displaced within Bosnia itselfto "safe" areas or regions controlled by their own ethnic group. It is difficult to say with any precision who the refugees are, why they left, what the circumstances were like in which they departed, what they left behind, how they made their journeys, what awaited them in their destinations, and how their lives have been irreparably damaged. Transformed and traumatized by the experience of war, they were traumatized once again through the process of becoming refugees.

The characteristics of the refugee population on the territories of former Yugoslavia (and beyond its borders) are now the subject of extensive research efforts by a number of scholars, some of whom have contributed their work to this issue of Refuge. This area of research is more than descriptive, however; these scholars understand the refugees produced by these wars as symptomatic of violent social upheaval in its post-cold-war renditionthe shifting of the burden of conflict more directly onto civilians, the creation and reinforcement of ethnic or national identity by efficient and effective media in service to the state, and the rapid fragmentation and shattering of individual life histories.

It should also be noted that this refugee population is the target group of what may turn out to be the largest humanitarian effort of its kind ever undertaken by the international community. In an era when the relationship between humanitarian intervention and military conflict is becoming increasingly nebulous, it is vital to understand more about the target population and the impact of assistance from a material, psychological, and political (including logistical) perspective. The Guest Editor of this issue of Refuge, Maja Korac, has drawn together a number of papers that shed some light on the internal and international facets of the conflict on the territories of the former Yugoslavia. By way of background, I offer some brief notes on the context of this research so that the reader may have a better appreciation of some of the obstacles placed in the path of such inquiries.

\section{Reconstruction of Identity}

In modern-day warfare, the distinction between civilian and non-civilian groups in battle zones is becoming increasingly blurred, to the extent that principles of international humanitarian law seem irrelevant. Within the logic of this stance taken by belligerents in ethnic conflicts, civilian populations are legitimate objects of violence, either in direct combat or through forced expulsion. Thus, the civilian's ethnic identity becomes the involuntary equivalent to a marker of military allegiance. In itself this might not be so unusual were it not for the

Edith S. Klein is a Research Associate at the Centre for Russian and East European Studies University of Toronto.

Maja Korac, Issue Guest Editor, is a Visiting Research Fellow at the Centre for Refugee studies (CRS), York University. 
fact that refugees from the Bosnian and Croatian wars became, for all practical purposes, "internal" refugees.

This state of affairs had several important ramifications. Above all, it threatened to homogenize ethnicidentity by making it a paramount category for the individual, who might in normal circumstances be indifferent to, vaguely aware of, or generally uninterested in that identity. Serbs, Croats, and Muslims became undifferentiated groups. At the same time, individuals whose ethnic identity was unknown, unclear, or had been relinquished experienced an unwanted identity crisis. ${ }^{3}$ This reconstruction of identity is also defined in terms of the "other" -a neighbour, close friend, or even family member, who now becomes an enemy. At the level of the individual, as well as of the state, the future is hostage to the past, as the redefinition of one's national group (a process which in normal circumstances might take generations) happens overnight, and is accompanied with much uncertainty. Croatian and Serbian scholars have already begun to document the traumatizing impact of such identity crises among refugees. ${ }^{4}$ In their contributions to the present collection, Slobodan Drakulic addresses the complex political backdrop that set the stage for these crises; Zarana Papic examines the dynamic development of nationalism, particularly in Serbia, while Zdenka Milivojevic analyzes the role played by the media in triggering ethno-national consciousness and interethnic conflict. Nergis Canefe Günlük provides a broader theoretical interpretation of the development of nationalism in the geopolitical space of former Yugoslavia.

The traumatizing experience of departure was compounded by the reception of refugees in their places of destination. Here we must consider the most important actors on the scene: humanitarian assistance organizations (United Nations agencies, international NGOs, domestic NGOs, and various ad hoc groups and individuals), the international diplomatic community, as well as the host govern- ments of Serbia (and the Federal Republic of Yugoslavia) and Croatia.

\section{Response to the Refugee Crisis}

The uprooting of the civilian population in various parts of Croatia and Bosnia-Herzegovina posed a great many dilemmas for the humanitarian assistance organizations designated to deal with refugee problems. ${ }^{5}$ For contextual purposes, it is necessary mainly to point out that humanitarian assistance organizations have been faced almost from the onset of the conflict with making choices between assisting in the removal of civilians to fulfil their humanitarian mandate, or protecting civilian populations from forced expulsion, but at great risk to themselves and their beneficiaries. ${ }^{6}$

UNHCR, the designated "lead" agency in the field, along with the International Federation of the Red Cross and Red Crescent Societies, have been particularly vulnerable to the charge of assisting with the process of "ethnic cleansing." The international diplomatic community, struggling unsuccessfully to find political settlements to this ethnic conflict, has also been regarded as contributing directly or indirectly, through such devices as the establishment of "safe" zones, to population shifts and to placing populations at risk. It has been further noted that international posturing on the conflict in ex-Yugoslavia has been influenced by Western reluctance to receive refugees. Lack of inspiration on the diplomatic front, and failure to grasp the political, as well as the humanitarian, repercussions of misinformed decisions, has had consequences that lend some credence to these charges. As the UN and NATO presence evolves in Bosnia-Herzegovina, the mandate for humanitarian intervention threatens to include military force, shifting the framework for settlement from the political to the military, and more than likely escalating the already dramatic and tragic population shifts. The impact of international posturing on the plight of refugees from the wars in Croatia and Bosnia-Herzegovina is addressed here by Michael Barutciski and Albrecht Schnabel.

The governments of the two major neighbouring host societies, for their part, were quick to recognize the influx of refugees into their territories as both a political asset and a liability. An essential element to the context is the fact that the governments of both Croatia and Serbia, since the collapse of the federation and its Communist regime, had been reconstructed as quasidemocratic multi-party systems with extremely problematic human rights agendas of their own, while at the same time militarily engaged, with fundamental interests at stake in the Croatian and Bosnian wars. Within the domestic frameworks of the two host societies, which were to a significant degree war-driven, refugees were not only the tangible consequence of an unjust and violent political conflict, but also had significant impact on the social order.

For the Milosevic regime in Serbia, refugees represented living proof of the victimization of Serbs. Very much a patriarchal society in many respects, as Zarana Papic notes in her contribution, Serbia absorbed more than 90 percent of its estimated half million refugees into private accommodation with relatives and friends. The inevitable tensions that arose within these arrangements, as temporary stays appeared likely to become long-term if not permanent, have been documented by a number of observers; to be sure, the widespread belief that refugees were living much better than the host population, thanks to humanitarian assistance, had some credible basis.

Serbian government authorities, however, exploited these tensions for the purpose of keeping the Serbian agenda within the conflicts of Croatia and Bosnia-Herzegovina at the forefront of the popular imagination, and to strengthen their case for the lifting of sanctions. Antiwar groups and independent assistance organizations have made extraordinary efforts to aid in the adjustment and support of refugee groups. 
For the Tudjman regime in Croatia, refugees (who numbered more than half a million) were a symbol of the struggle to return contested territories to Croatian control (indeed, refugees of Croatian nationality are usually referred to as displaced persons). As in Serbia, a significant percentage of refugees were privately housed, with similar consequences for the social order. Particularly problematic for the Croatian government were the large numbers of Muslims, whose mistreatment from time to time at the hands of Croatian authorities has been the primary concern of opposition and antiwar groups in that republic. ${ }^{7}$ Any efforts to facilitate Muslim refugees' departure to third countries have been interpreted as simply another form of "ethnic cleansing."

While both governments have manipulated the social tensions aroused by the presence of large refugee populations, they have also from time to time made use of various strategies to reverse population movements, expelling refugees and returning them to their homes (or in the case of men of military age, to the front). Such actions were intended to earn credit among the host population by giving the appearance of alleviating the burden of support, shifting the blame for the conflict onto the target populations, and distancing the regimes' constituents from the responsibility for conflict. The manipulation of figures pertaining to the influx and outmigration of refugees also disguised the acceleration of the "brain drain," as many individuals with sufficient resources were able to leave their country with fewer difficulties. ${ }^{8}$

\section{Postwar Prospects}

As prevailing social policies change according to the availability of resources and the degree of fit with the political agenda of the day, the situation of refugees in Croatia, Serbia, and Bosnia-Herzegovina is by no means static. What is even more uncertain is the long-term prospects for these uprooted individuals, many of whom simply may never be able to return to their homes. Refugee populationsmade up largely of women, children, and the elderly-are by definition extremely vulnerable, and will face tremendous obstacles once they are in a position to rebuild their lives. Wherever they finally settle, however, they have every right to expect credible human rights protection from the state in which they reside.

Even a cursory survey of the reconfigured territories of the former Yugoslavia and their neighbouring states suggests that it may be some time before this expectation can be fulfilled. The current regimes in Croatia and Serbia are consumed with the tasks of nation-building and of sustaining military projects, tasks that do not appear to include emphasis on development of an ethos of pluralism and tolerance. Other host countries, such as Germany, face increased domestic resistance against any further influx of refugees, as noted in Albrecht Schnabel's piece. Wherever they find themselves, refugee populations are regarded as a social and economic burden whose tenancy is hoped to be as short as possible. When this kind of upheaval occurs as a result of the failure of old states and the creation of new ones, the prospects of bringing security to the victims seem very dim indeed.

A ten-year-old boy displaced by the war in Bosnia, who was a guest at one of the Soros Foundation's camps for refugees, recently pondered his fate: "I was a refugee last year, and a refugee before that. I think I am going to be a lifelong refugee." A first step in preventing this kind of tragic destiny from materializing is to determine, through a clearer understanding of the contributing circumstances, how states, nations, and individuals can manage these traumatized populations, and prevent refugee-producing conflicts in the first place.

\section{Notes}

1. A useful survey of current refugee-producing ethnic conflicts can be found in Kathleen Newland, "Ethnic Conflict and Refugees," Survival, Vol. 35, no. 1 (Spring 1993): 81-101.
2. Larry Minear, et al., Humanitarian Action in the Former Yugoslavia: The U.N.'s Role, 19911993 (Providence: Brown University, Thomas J. Watson Jr. Institute for International Studies, Occasional Paper No. 18, 1994), pp. 11-17. By this calculation, individuals displaced by the wars in Croatia and Bosnia-Herzegovina constitute more than 20 percent of the present world population of refugees.

3. Ruza Petrovic estimates that approximately 13 percent of marriages in Yugoslavia (and as high as $\mathbf{2 7}$ percent in Vojvodina) were between members of different ethnic groups (1981 figures); accurate estimates of the numbers of children of mixed ethnic background were not available at the time of writing. Ruza Petrovic, Etnicki mesoviti brakovi u Jugoslaviji (Belgrade: Institut za socioloska istrazivanja Filozofskog fakulteta u Beogradu, 1985).

4. See, for example, Nada Korac, "The Confining of Children's Minds: Cognitive-Developmental Effects of War Atmosphere," unpublished manuscript (author's files); Maja Korac, "Women Refugees from the Former Yugoslavia: Problems of Disintegrated Identity," paper presented to the Conference on Gender Issues and Refugees: Development Implications (Centre for Refugee Studies and Centre for Feminist Studies, York University, May 9-11, 1993); and forthcoming work by Mirjana Morakvasic-Muller and Zdenka Milivojevic. In Zagreb, the Institute for Migrations and Nationalities has been established by Silva Meznaric within the University of Zagreb; works by Zagreb-based scholars can be found in issues of Migracijske teme; see also, for example, Dean Ajdukovic (Ed.), Psiholoske dimenzije progonstva (Zagreb: Alinea, 1993).

5. These dilemmas are dealt with extensively in Minear, op. cit.

6. A rather typical statement concerning the priorities of humanitarian organizations in decision-making with respect to this dilemma can be found in UNHCR/UNICEF Joint Statement no. 2, "Further Considerations Regarding the Evacuation of Children from Former Yugoslavia," 16 December 1992, in Everett M. Ressler, Evacuation of Children from Conflict Areas: Considerations and guidelines (Geneva: UNHCR and UNICEF, 1992).

7. For an example of the type of work being carried out by independent organizations in Croatia, see Centre for Women War Victims, Interim Report, compiled by Martina Belic and Vesna Kesic (Zagreb: August 1993), section IV, "Report on the Work in Refugee Camp 'Studenski grad'."

8. Komesarijat za izbeglice republike Srbije, Izbeglice u Srbiji (Beograd: Sept. 1, 1993), a periodical publication issued by the Commissariat for Refugees for the Republic of Serbia, gives sample figures. 